\title{
Article \\ Between Messianism and Zionism-The Religious Proto-Zionists: Transforming from Theurgic-Symbolic Messianism to Zionist Activism
}

\author{
Asaf Yedidya (D)
}

Citation: Yedidya, Asaf. 2022.

Between Messianism and

Zionism-The Religious

Proto-Zionists: Transforming from

Theurgic-Symbolic Messianism to

Zionist Activism. Religions 13: 52.

https://doi.org/10.3390/rel13010052

Academic Editors: Amir Mashiach

and Isaac Hershkowitz

Received: 3 December 2021

Accepted: 31 December 2021

Published: 6 January 2022

Publisher's Note: MDPI stays neutral with regard to jurisdictional claims in published maps and institutional affiliations.

Copyright: (C) 2022 by the author. Licensee MDPI, Basel, Switzerland. This article is an open access article distributed under the terms and conditions of the Creative Commons Attribution (CC BY) license (https:// creativecommons.org/licenses/by/ $4.0 /)$.
Israel Heritage Department, Ariel University, Ariel 40700, Israel; asafy@emef.ac.il

\begin{abstract}
The 19th century, which began with the immigration to Eretz Israel of 511 disciples of the Vilna Gaon (HaGra) and their families from Lithuania for religious reasons between 1808-1811, ended with the arrival of tens of thousands of Hovevei Zion from Russia and Romania for nationalistic motives, beginning in 1882.This article deals with the differences between the doctrine of redemption of the Vilna Gaon's disciples and the Zionist ideology of Hovevei Zion in light of the thought of the religious proto-Zionists. Rabbi Zvi Hirsch Kalischer and Rabbi Eliyahu Guttmacher who were the proto-Zionists actually served as transformers from theurgic-symbolic messianic activism to realistic Zionist activism through their combined adoption of all these active approaches and the shift in emphasis from the symbolic to the realistic. Putting them all in the traditional messianic camp or the modern national camp distorts the picture. The great innovation of their doctrine was the transformation of the idea.
\end{abstract}

Keywords: messianism; Hibbat Zion; Zvi Hirsch Kalischer; Elijah Guttmacher; Vilna Gaon's disciples; proto-Zionists

\section{Introduction}

During the nineteenth century Jewish settlement in the Land of Israel changed, both in terms of the number of Jews and their distribution, and also in terms of the nature of the settlers: their countries of origin, religious attitudes, occupations, and the future of the settlement. The century, which began with the aliyah (immigration to Eretz Israel) of 511 disciples of the Vilna Gaon (HaGra) and their families from Lithuania for religious reasons between 1808-1811, ended with the arrival of tens of thousands of Hovevei Zion from Russia and Romania for nationalistic motives, beginning in $1882^{1}$. The Vilna Gaon's disciples and their descendants were major partners in shaping what is known in Zionist historiography as the Old Yishuv, while the immigrants in the first wave of Zionist aliyah established its rival, the New Yishuv ${ }^{2}$. The Zionist group's awareness that they were rebelling against the traditional Jewish world intensified the differences between the two Yishuvs and between the Zionist aliyah and the one that preceded it, portraying them as two distinct and opposing worlds. However, the descendants of the Vilna Gaon's disciples, impressed by the success of the Zionist project, sought acknowledgement for their elders, painting them and their motives for aliyah in Zionistic colors and portraying Zionist aliyah as the continuation of their initial efforts. Historiography supports their efforts, but they are not backed by contemporary historical sources (Barnai 1995, pp. 173-74; Etkes 2019, pp. 44-52).

In this article I seek to re-examine the aspects of continuation and revolution that marked the Zionist aliyah and its intentions, and the aliyah of the Vilna Gaon's disciples and their motives, by examining the worldview of the religious proto-Zionists who were active in the late nineteenth century, and how it links these two phenomena. To this end I will focus on the characteristics of each aliyah and discuss the teachings of the religious proto-Zionists in this context. 


\section{The Aliyah of the Vilna Gaon's Disciples}

The study of Jewish messianism in modern times has engaged many Zionist and Israeli historians. As the time frame of the subject approaches the final decades of the nineteenth century - the time of the conceptual and practical formation of Zionism, the modern Jewish national movement- the topical question of the connection between these two phenomena arises and fundamental historiographical disagreements appear (Idel 2012). The controversy over the motives for the aliyah of the Vilna Gaon's disciples has been going on for more than thirty-five years and refuses to die down. On one side we have historian Arie Morgenstern, who says that the aliyah of the Vilna Gaon's disciples which began in 1808 stemmed from an active messianic desire to bring Redemption closer in a natural way through human endeavor, because according to the Book of the Zohar the year 5600 $(1839 / 40)$ would mark its beginning. According to Morgenstern, when their hopes for Redemption were shattered in 1840 a spiritual crisis broke out in their Jerusalem community and they abandoned the idea of bringing about Redemption through nature. In the course of time Kabbalah scholar Raphael Shuchat came to side with him, although he disagreed with Morgenstern about the centrality of the year 5600 in the messianic consciousness of the Vilna Gaon's disciples and claimed that the idea of Redemption through nature continued to inspire their descendants in the second half of the nineteenth century. Both of them maintained that the aliyah of the Vilna Gaon's disciples was the fulfillment of the spiritual will of their rabbi (Morgenstern 2006; Shuchat 2008).

Historian Israel Bartal criticized Morgenstern's theory. He argued that placing the messianic expectations of the year 5600 at the center of the Old Yishuv, especially at the heart of the kollel of the Vilna's Gaon's disciples during the preceding thirty years, and attributing all the changes in the kollel that occurred in the second half of the nineteenth century to the disappointment of their hopes, was unfounded and exaggerated. According to Bartal, the sole motive for the aliyah of the Vilna Gaon's students was "Torah study according to the Gaon's method in Eretz Yisrael [...] and since Eretz Yisrael is special above all others, it is better to study here than anywhere else." (Bartal 1994, p. 54 )

In his recent book, historian Emanuel Etkes criticized Morgenstern's argument, which he claimed was influenced by the traditions of the immigrants' descendants who sought to attribute to their forebears a kind of early redemptive activism, following the success of Zionist immigration in the late nineteenth and early twentieth centuries. According to Etkes, the aliyah of the Vilna Gaon's disciples was a link in a traditional chain of aliyah dating back to the thirteenth century, and "the uniqueness that characterized their aliyah was their deep devotion to the ideal of Torah study through asceticism, as exemplified by the Vilna Gaon." He deduced this from several contemporary aliyah leaders, who described their efforts to establish batei midrash and Torah study using the methods of their teacher, the Vilna Gaon (Etkes 2019, pp. 35-43).

Detractors of Morgenstern have criticized his interpretation of a significant number of contemporary sources, arguing that their reading has led them to different conclusions. They have warned against relying on later sources, which are beset by anachronisms and even some historical rewriting, and seek instead to rely on sources from the first years of the aliyah of the Vilna Gaon's disciples, which do not indicate any sense of mission, do not refer to his spiritual will to immigrate to Eretz Israel, and do not ascribe any active messianic motives to the immigrants. Sources that unequivocally indicate active messianic expectations among the immigrants, such as the messianic attempt to reclaim the courtyard of the Hurva in Jerusalem (1820) and Rabbi Israel of Shklov's appeal to the ten tribes to renew the Sanhedrin and speed up the Redemption (1831), were explained as later developments and/or expectations that motivated some, but not all the immigrants (Bartal 1994, p. 251). According to these critics, the main motive for aliyah was the establishment of a center for Torah study in Eretz Israel, which is a traditional aspiration far removed from active messianism and certainly from the notion of Redemption through nature preached by the proto-Zionists. They maintain that the idea of Redemption through nature could not have occurred to East European Jews in the early nineteenth century. 


\section{Theurgic-Symbolic Messianism}

I would like to propose a different approach to explain the motives of the Vilna Gaon's disciples in making aliyah, based on contemporary and later sources, unaffected by anachronism and trends towards historical rewriting. I will discuss the broader significance of their endeavors by examining their world of concepts and that of their successors.

It is true that the disciples of the Vilna Gaon came to Eretz Israel to establish a center for Torah study, as can be seen from a number of contemporary sources (Etkes 2019, pp. 39-42). Moreover, they came in order to renew the observance of the commandments that can only be observed in Eretz Israel. Rabbi Chaim Katz of Pakrai, one of the leaders of the newcomers, wrote in a letter dated 1809, the year of his aliyah, that on the advice of Rabbi Chaim of Volozhin they bought land in the Safed area so they could observe the commandments that depended on the land, also for the sake of the Jews abroad who had sent them money for the observance of these commandments. "As to the matter of donations that were sent to us for this purpose, we have already bought land, to the knowledge of our dear friend, the great hassid Chaim of Volozhin [...] and we will buy more land when the opportunity arises, depending on the time and place." (Ya'ari 1943, p. 341) In another letter sent by the disciples of the Vilna Gaon from Safed in the year 1810, they clarified their mission to observe the commandments that pertain to Eretz Israel:

It is also known that with the money you sent for the observance of commandments that pertain to Eretz Israel we have purchased land and with the produce that grows therein, together with our partners. And we will also buy more land at the right time and place (Ya'ari 1943, p. 336).

From the first part of this long letter, Bartal and Etkes deduced that the sole motive of the disciples for making aliyah was to study Torah in seclusion in Eretz Israel, because they wrote that they had come in order to "connect the four amot [cubits] of plain halakha with four amot of the Holy and Pure Land." (Etkes 2019, p. 41; Bartal 1994, p. 21) From this part of the letter Morgenstern understood that in the opinion of the newcomers, Redemption had been delayed because the Land of Israel had been forgotten, as it is said "Forgetting Eretz Israel prolongs the length of the Diaspora." (Morgenstern 2007, p. 17) However, this part of the letter enumerated the virtues of the land, among them 'the good multiplicity of its commandments', that is, the commandments that depend on the land (Ya'ari 1943, p. 331).

Although Torah study in the Land of Israel and the renewed observance of the commandments that depend on the land have a broader meaning that paints them in the light of Messianic activism, they are not realistic, or redemption through nature, but rather mystic or theurgic-symbolic, in other words, redemption through religious deeds. That is, the authoritative religious source of the act is important, not the rational connection between action and outcome.

In her article "The Messianic Idea and Zionist Ideologies", Jody Myers pointed to four different ideologies regarding the return to the Land of Israel in the 19th and 20th centuries: passive messianism, active messianism, secular Zionism, and non-messianic religious Zionism. She defined active messianism as more rational and considerate of the laws of nature, encompassing both the students of the Vilna Gaon and Rabbi Kalischer (Myers 1991). In her book, which she dedicated to him, she called his doctrine 'realistic messianism'. In my opinion, there are two types of active messianism: theoretical-symbolic messianism, which tries to influence the upper worlds through religious means, with no regard to reality, and realistic messianism, which focuses on actual success and chooses religious means for its achievement, such as renewing the observance of commandments that depend on the land, and neutral factors such as substantial aliyah, land acquisition, and agricultural settlement.

According to the world of concepts of the disciples and their descendants, which was influenced by Kabalistic literature, both the study of the Torah in Eretz Israel and the observance of the commandments that depend on the Land have the Kabbalistic import of repairing the world, which ultimately leads to Redemption. Torah study in Eretz Israel and 
keeping the commandments that depend on the Land are the key to hastening Redemption. These practices are far more effective in this context than studying the Torah abroad and keeping the rest of the commandments.

The connection between the attempts to renew the observance of the commandments that depend on the Land and the perception that this is a catalyst for bringing redemption closer is clear from a letter sent by the heads of the Ashkenazi community in Jerusalem, the second generation of immigrants, to Moses Montefiore in 1839:

We have a tradition handed down from our forefathers that if we observe the Holy Torah in the Holy Land as well as the commandments that depend on the Holy Land, then everything will be strengthened and united and abundance will descend from the source of blessings [...] Awakening from below is required to inspire awakening from above. Until when will our Holy Land lie destroyed and desolate and God's people be an example of disgrace and taunts? (Baron 1937, p. 304)

In this letter the writers noted the tradition they inherited from their immigrant parents, that the observance of the commandments that depend on the land is in the nature of human endeavors achieved through the efforts of the religious, which hasten Redemption.

Another source that explains the connection between Torah study in Eretz Israel and the renewal of the commandments that depend on Eretz Israel and their role in bringing about redemption is the letter written in 1873 by Rabbi Yitzchak Kahana, a student of Rabbi Yitzhak Eizik Chaver, who was himself a student of Rabbi Menahem Mendel of Shklov—a senior student of the Vilna Gaon, who was instrumental in renewing the Ashkenazi Community in Jerusalem, to Rabbi Zvi Hirsch Kalischer ${ }^{3}$. Kahana was born in 1814 in Kolno, in the northeastern Polish Congress, and in the year of the death of Rabbi Chaver (1852) he immigrated alone to Eretz Israel and settled in Jerusalem (Kahana 1875, introduction), where he became a member of the Lomza-Suwalki Kollel. Kahana was a wise and well-liked student. He published Karo's commentary on Sefer Yetzira (Jerusalem 1875) and also published two volumes titled Toldot Yitzhak (Jerusalem 1879, 1884). Contrary to popular belief, he advocated the study of Kabbalah for all, not just a chosen few, and believed that this was especially important in his time, which he believed to be very close to the Redemption. He died in 1900 (Shuchat 2015).

The letter is actually in two parts. The first was written in 1873 for Kalischer and included a collection of Kabbalistic traditions from the Beit Midrash of the Ari (R. Yitzchak Luria, 1534-1572) and from the Beit Midrash of HaGra relating to matters that hasten Redemption. It ended with a practical plan for establishing a "Society for Settling Eretz Israel". The second part, written in 1858, included a proposal to establish an Ashkenazi beit midrash in Jerusalem. The letter from 1858 was attached to prove to Kalischer that he favored active Messianism which is not satisfied with mere preservation of what already exists, although his activism was more theurgical and symbolic, similar to that of the Kabbalists in Safed in the sixteenth century and those in Jerusalem in the eighteenth century (Morgenstern 2015, pp. 127-77).

Kahana's letter was inspired by an article published by Kalischer in HaMaggid newspaper at the end of 1872 (Klausner 1947, p. 422). In this article, Kalischer focused on the possibility that was dawning in Eretz Israel to return to observing the commandments that depended on the Land. According to him, unlike in former times it was now legally permitted for Jews to own land, which is a condition for observance of these commandments. The situation now allowed for agricultural settlement. He therefore called for support for Jews who were becoming involved in agriculture and the observance of these commandments, noting that he sees this as a catalyst for Redemption:

And if we establish His society [agudato] on the land, then righteousness will shine down from Heaven and God will be pleased by our deeds. God willing, He will be placated by our labor, shine light on His nation and hasten Redemption, speedily in our day, amen (Translated in: Myers 2003, p. 209). 
Kahana, who felt that the words of Kalischer in HaMaggid echoed his own beliefs and ideas, wanted to offer his own plan of action. He began his letter to Kalischer by quoting from his letter of 1858, in which he proposed establishing a beit midrash in Jerusalem that would be attended by at least ten people on a regular basis—the halakhic definition of a city for certain purposes ${ }^{4}$. A more significant religious definition of Jerusalem was, in Kahana's opinion, a necessary condition for the Redemption; a condition reminiscent of Rabbi Yisrael of Shklov's appeal to the Ten Tribes for the renewal of ordination, which was another religious condition for the Redemption (Morgenstern 2006, pp. 103-10; Morgenstern 2015, pp. 356-75). Kahana believed that Torah study in this beit midrash would evoke divine intervention. He attributed this view to HaGra.

Kahana laid out his updated plan, beginning with the establishment of an Ashkenazi beit midrash in which students would both study and pray according to Kabbalist traditions. He based his idea on quotations from the Zohar and the writings of the Ari. According to him, this idea of "Torah and prayer in the style of the Ari is an internal matter for restoring the crown [of Torah] to its former glory" ${ }^{\prime \prime}$. The concept of repairing the world is here taken from the Ari and means selecting sparks by religious means accompanied by the right intentions, a process whose cumulative result is the coming of Redemption in all worlds: the Redemption of Israel, of the entire universe, and the Divine (Shuchat 2008, pp. 159-60; Idel 1998, pp. 154-82).

The second part of his plan related to Kalischer's article. It focused on the idea of renewing the observance of those commandments that depend on the Land, which Kahana defined as an external matter-as opposed to study and prayer, which are internal matters:

But there is another external matter for the repair of the world and that is to develop charity for the Land in order to keep the commandments that depend on it, as is written in the book by the Ari, so that our Messiah will soon come in our day.

To substantiate this idea, Kahana brought evidence from Kabbalistic traditions attributed to HaGra and Menachem Mendel of Shklov. One of his arguments is taken from HaGra's commentary on Sefer Yetzira:

Repair of the shechina which is the end of our exile also depends on these three things [...] The repair of these three things, world, year, and soul, is in the Land. As it is written in parshat Behukotai, "Then the Land will desire..." This is in terms of the place. Regarding the Sabbaths, this is in terms of time, which is a year, Then will their uncircumcised heart be appeased from their sins, which is in terms of the soul. ${ }^{6}$

According to Sefer Yetzira, the secret of creation is concealed in the connection between space-world, time-year and man-soul, and is expressed in the harmony between the symbols of this structure: the zodiac, the months, and the organs of man. In Kabala, the correction, that is, Redemption, will come when there is accord between the highest expressions of this structure: Eretz-Israel in space, the year of the shmitta in time, and the people of Israel in man. The secret of Redemption is hidden in the observance of shmitta. This tradition cannot be found in the Vilna Gaon's commentary on Sefer Yetzira published by Kahana. According to another tradition brought by Kahana on behalf of Menachem Mendel of Shklov, the ingathering of the exiles depends on providing gifts for the poor-leket, shikcha and pe'ah: "I have found in the writings of Menachem Mendel that the ingathering of the exiles depends on these three things. And it is known that all his words are from his own teacher"7.

Kahana emphasized that the renewal of the observance of commandments that depend on the land should follow the strictures of halakha as well as HaGra's method with regard to counting the years of shmitta, which means that the shmitta year must be kept for two consecutive years. This would certainly lead to great financial loss. In his words "by nature they will not succeed" 8 .

This active messianic program included both internal correction (tikkun penimi), through Torah study and Kabbalistic prayer, and external correction (tikkun chitzoni)—in 
the renewal of the observance of commandments that depend on the land in all their particulars. Prominent in this program was a theurgic-symbolic messianism which ignored reality. The main thing is the act, which is effective in the upper worlds even if its result can be harmful here on earth. A two year shmitta to ensure that every method is met is supposed to lead to such sanctification, but it has no real basis 'according to nature', and therefore it will surely fail, and any economic investment will be lost. This approach was the antithesis of that of Kalischer, who tried to prove at every opportunity that his plans to populate Eretz Israel were realistic, although he also employed the same kabbalistic phrases used by Kahana. In a discussion with the heads of the Alliance Israelite Universelle (AIU) in 1874, while preparing for Mikveh Israel's first shmitta, he made every effort to facilitate work in the fields and vineyards in the seventh year (Yedidya 2015, pp. 68-69).

Kahana's letter also indicates that Torah study in Eretz Israel is a catalyst for Redemption. Action on both levels-internal, Torah study, and external, observance of the commandments that depend on Eretz Israel-are two sides of the same theurgic-symbolic messianic coin, operating through both body and soul (Shuchat 2003, pp. 165-66). The qualitative difference between the study of the Torah in Eretz Israel and in the Diaspora is made clear in the letter written by HaGra's disciples in Safed, who wrote that "the Torah returns to its host [Eretz Israel]." (Ya'ari 1943, p. 330) The attainment of the Torah in Eretz Israel is superior to its attainment abroad. This opinion is also clear from the letter of Rabbi Chaim Katz, who wrote that "the Holy Land is more conducive to Torah than the Diaspora." And "whosoever wishes to devote himself to Torah and worship can do it better here than abroad, because of its sanctity", although he also gave a rational reason for this: "day and night are equal and spacious for attaining the Torah, and the truth becomes clearer." (Ya'ari 1943, pp. 340-41)

I believe the two traditions quoted above shed light on the beginning of the aliyah of HaGra's students. They date back to the 1830s and 1870s and precede the establishment of Hibbat Zion, immigration to Eretz Israel and the astounding success of the Zionist movement. The context of the second is the exchange of ideas with Kalischer, whose plans for the settlement of Eretz Israel were not a real success. From these traditions we learn about the importance of the idea that renewing the commandments that depend on the Land will hasten the Redemption, according to the Vilna Gaon and Menachem Mendel of Shklov. It is possible to learn from these traditions and from the historical sources from the beginning of the aliyah of HaGra's disciples who upheld them, that this aliyah was accompanied by an active messianic conception, but it was theurgic-symbolic activism and not realistic activism like that upheld by the proto-Zionists. Indeed, at the beginning of the 19th century, unlike in the second half, any realistic plan to populate Eretz Israel was baseless. During this period, the Jews in the Land of Israel suffered from instability, insecurity, and arbitrary taxation, and were forbidden to purchase land and even renovate their synagogues in Jerusalem. Travel from Europe to Eretz-Israel was difficult, limited, and not suited for mass migration. The political change for the better came only during Muhammad Ali's rule over Eretz Israel in the 1830s, and especially after the Crimean War and the increased dependence of the Ottoman Empire on European countries. Nevertheless, it was possible to see that it could realistically be achieved. One can see in the appeal of the disciples to redeem the Ashkenazi court in Jerusalem and to rebuild the Hurva synagoguedespite the political aspect of these steps-as well as the search for the Ten Tribes to renew ordination, the same messianic theurgic-symbolic activism that was nurtured more from a Torah source than from any basis in reality. Thus, in his appeal to the Ten Tribes, Yisrael of Shklov based himself on the Zohar, Midrash Miyalkut Tehilim and various halakhic sources on the renewal of ordination, rather than offering a rational-realistic explanation of how this move would promote Redemption (Morgenstern 2006, pp. 104-5) ${ }^{9}$. However, the transition from active theurgic-symbolic messianism to realistic messianism was no longer as radical a perceptual reversal as the transition from passive messianism to active messianism. It can be seen as a gradual ideological development nourished by the political reality. But even the opposition to Redemption through natural means, which was omitted by proto-Zionists, 
was not really a change of heart. It can be explained by Orthodox fears of the modernization of the Yishuv, which would bring reform and secularization, as had happened in Western and Central Europe.

\section{The First Zionist Aliyah}

In contrast to the aliyah of HaGra's disciples, the motives, context and history of the first Zionist aliyah are known and agreed upon by scholars, even without dwelling on the story of the Bilu'im, who were in many ways ahead of their time (Shimoni 1995, pp. 29-30).

The Emancipation, and the successful integration of Jews within the general society which followed, elicited a reaction in the form of modern anti-Semitism, whose spokespersons sought to turn back the clock and cancel the equal rights granted to Jews. This new-old hatred led many Jews to realize that Emancipation had not solved the problems of Jews in the Diaspora, and that the solution must be sought through other channels. At that time the majority of world Jewry lived in the Russian Empire and were geographically limited. The economic situation was catastrophic. Moreover, Russian Jews suffered from frequent pogroms. These factors spurred them to leave the Russian Empire and seek new horizons. The success of the movements of national minorities in multinational empires in Europe, such as Greece and Italy, provided a model for a possible solution.

In the 1880s, after several pogroms in Russian Jewish settlements in the south, a Jewish national movement-Hibbat Zion-was founded, promoting immigration to the Land of Israel and the establishment of colonies that would serve as a Jewish national entity.

The leader of Hibbat Zion, Yehuda Leib (Leon) Pinsker (1821-1891), formulated the overarching goal of the movement in his book Auto-Emancipation (1882), although this specific work did not support a Palestine-centered nationalism, "The creation of Jewish nationalism, of a people dwelling in its land: the self-liberation of the Jews, their equal status as a nation among nations by achieving their own homeland." (Pinsker 1960, p. 47) His associate Moshe Leib Lilienblum (1843-1910), who was also one of the movement's leaders, defined its realistic goals, in terms of time and space:

We must strive for the settlement of Eretz Israel by Jewish farmers and settle our brethren in such a way that for a hundred years the Jews will be able to almost entirely leave Europe, which is alienated from them, and settle in our ancestral

land, to which we have a historic right which was not ended or lost when our governance was lost, in the same way that the right of the Balkan peoples to their land did not end with the loss of their governance (Lilienblum 1953).

The main bloc of the movement's leadership was composed of educated people who had previously supported a kind of Jewish cultural nationalism, and now sought to add collective self-realization in the historical territory. More groups among Russia's Jews began to identify, one way or another, with the new goals.

Jews with diverse religious views tried to cooperate: Secularists who were deeply rooted in Russian intelligence, radical Hebrew maskilim who were not observant, moderate Hebrew maskilim, and even Orthodox rabbis. A smaller group of Jews from Romania also joined the movement ${ }^{10}$. The movement was also supported by the large communities in Western Europe and the United States, most of them made up of immigrants from Russia.

From 1882 thousands of Russian and Romanian Jews immigrated to the Land of Israel, spurred by the realization that Jews had no future Russia and Romania, and harboring a national awareness and a desire to settle the Land of Israel. In the first twenty years the immigrants established more than twenty agricultural colonies. Until that time, Jews in Eretz Israel had lived mostly in Jerusalem, Tiberius, Safed and Hebron. By the end of the 19th century, Jewish immigrants had doubled the number of Jews in the Land of Israel.

\section{The Proto-Zionists}

Towards the end of the nineteenth century, a small group of Jewish thinkers in Europe became known in Zionist historiography as the proto-Zionists. Although Zionist ideologues have used this controversial term extensively and uncritically, ultimately even 
contemporary historians have adopted it, after narrowing it down and defining its boundaries. This group did not engender an unusual aliyah movement but understanding their ideology is important if we are to understand the connection between the aliyah of the Vilna Gaon's disciples and the first Zionist aliyah.

The early nineteenth century witnessed a trend to reevaluate the future of Jews, Judaism, and national ideas about the return to the Land of Israel and the resettlement of the land. Jewish thinkers who engaged with these topics came from a variety of backgrounds. Moses Hess (1812-1875), a native of Bonn, Germany, received a traditional Jewish education but abandoned religious observance when he was still quite young. David Gordon (1831-1886), a native of Lithuania, pursued secular studies while attending a yeshiva in Vilna. In 1858 he moved to Lyck in Eastern Prussia and became deputy editor of the Hebrew weekly HaMaggid. Several were dedicated to the rabbinic profession, such as Rabbi Judah Alkalai (1798-1878), who was born in Sarajevo and served as a preacher in Semlin in Serbia, and Rabbis Elijah Guttmacher (1796-1874) and Zvi Hirsch Kalischer (1795-1874), who sought to realize nationalist and communal goals in the Prussian regions of Posen and Pomerania.

These and other figures who were active in the generation prior to Hovevei Zion and whose ideas resembled those of Zionism, have been labeled by Zionist historians the "proto-Zionists." Although they preceded Zionist national-political recognition by two generations, their writings constituted an important foundation for Zionist ideology. After the State of Israel was established and academic research flourished on the topic of Zionism as an ideology and a historical movement, lively debates surrounded the origins of Zionist ideology and the degree of connection and similarity between the teachings of the proto-Zionists and the Zionist doctrine that ultimately materialized in a political movement. Was the perception of these proto-Zionists in the first half of the twentieth century anachronistic, stemming from a projection of modern national ideology onto their traditional messianic doctrine? And was the similarity principally one of terminology, not of essence? (Ettinger 1978, pp. 15-16) Or is there evidence of a modern national outlook in the doctrines of the proto-Zionists, despite their overwhelming use of traditional terms? (Dinur 1955, pp. 58-59; Laqueur 2003, pp. 54-55) Jacob Katz emphasized the sociological aspect of the proto-Zionists over their ideological partnership with Zionism, focusing on the social convergence around these ideas. He included in this group the socialist philosopher Moses Hess and the traditional rabbis Judah Alkalai, Elijah Guttmacher and Zvi Hirsch Kalischer, who worked towards social cohesion around the idea of the return to Zion, through the Kolonisations-Verein für Palästina (the Society for the Settlement of the Land of Israel) that was founded in Frankfurt an der Oder in 1860. However, their reasoning was quite dissimilar: Hess was inspired by modern nationalism whereas the rabbis were motivated, according to Katz, by traditional messianism (Katz 1979, pp. 263-84).

In contrast to Katz, Gideon Shimoni considered the differences in their basic assumptions and concluded that the proto-Zionists could only include personalities such as Moses Hess, who believed the Jews were an entity distinguished by characteristics that related not only to religion but also to the modern concept of a nation. He maintained that the conceptual pattern that motivated Alkalai and Kalischer and shaped their goals belonged in the realm of traditional messianic longing rather than that of modern national ideology, and therefore they should not be ranked with Hess, although they carved their own path to the Jewish nationalism whose influence is evident in religious Zionism (Shimoni 1995, pp. 52-82).

Whether or not this group of rabbis is regarded as proto-Zionists, they constituted a distinct ideological group with clearly defined characteristics. With Hess, its members shared a common worldview that centered on the return to Zion and the rebuilding of the Land, and they sought to realize it in their lifetime through every available means ${ }^{11}$. No less important was the shared understanding that the period in which they were living was unprecedented with respect to the genuine possibility of realizing the vision of the return to Zion. Hess ably formulated this insight, especially in the context of the growth of 
national movements among the people of Europe, who lived in multinational empires and were beginning to demand and even fight for political independence (Hess 1955, p. 86).

Apart from the primacy of traditional sources and messianic-redemptive concepts in the writings of mid nineteenth-century rabbinic figures, historical-religious interpretations of contemporary events were equally pivotal to their ideology and were consistent with pre-Zionist ideas. It was understood by all of the foregoing rabbinical activists that the redemption of Israel would initially be realized only by natural means-great immigration to the Land of Israel and extensive settlement, preparing the ground and diplomatic activity, on the one hand, while preparing the reality that this activity was actually being directed by God.

In fact, some of these rabbis combined a theurgic-symbolic messianic conception with a practical messianic conception of Redemption through nature. Historical changes indicated that the time for Redemption was at hand and human action would hasten its coming. This had to be done both theurgically and symbolically, like HaGra's disciples, and realistically, through aliyah and Jewish settlement, like the method of Moses Hess, whose salient points were published in his pre-Zionist book, Rome and Jerusalem: The Last National Question $(1862)^{12}$.

\section{Rabbis Zvi Hirsch Kalischer and Elijah Guttmacher}

The most notable thinker in this group was Rabbi Zvi Hirsch Kalischer from Thorn, Pomerania. He was born in Lissa in the province of Posen. After the division of Poland in 1793 Lissa came under Prussian jurisdiction along with the rest of the province. In his youth he studied under two of the greatest Orthodox rabbis of his generation: Jacob Lorberbaum of Lissa (1760-1832) and Akiva Eger of Posen (1761-1837). He married Gittel Cohen from Nieszawa in 1819, and from 1823 until his death he served as presiding judge on the bet din (rabbinical court) of the town of Thorn ${ }^{13}$.

Kalischer was recognized as a leading halakhic authority. His Mozna' im la-mishpat (1855) was widely admired. He also focused on Jewish philosophy and Bible commentary. His writings touched on current events and included polemics against the Reform movement and modern literature, which, he believed, was undermining Jewish tradition.

He embarked on his proto-Zionist activities in 1836 when he approached Amschel Rothschild (1773-1855), the oldest son of the founder of the Rothschild banking dynasty, in Frankfurt, requesting that he use his influence to raise funds to purchase the Land of Israel from its rulers. He then entered into correspondence with his mentor, Rabbi Akiva Eger, and with the latter's son-in-law, Rabbi Moses Sofer, on the subject of halakhic rulings regarding his idea of renewing the practice of sacrifices. In 1844 he appealed to Moses Montefiore (1784-1885) with a proposal similar to the one he had made to Amschel Rothschild (Green 2010, pp. 211, 474). These activities, however, remained hidden from the public. He was best known for his proto-Zionist book Drishat Zion (1862) and his indefatigable efforts on behalf of the settlement of the Land of Israel, which continued until his death in 1874 .

He did not view the historical events of his time through the prism of pragmatic politics alone but considered them from the perspective of religion. He saw in the unfolding of historical events evidence of divine providence guiding Israel on the path to redemption. Most importantly, he believed that Emancipation was a decisive moment in the annals of the Jewish people, and that it befitted the beginning of human action toward redemption. Emancipation was granted by God so that the people of Israel could work toward Redemption. "Not as in former years when Jacob was lowly and could not lift his head. Now He will tell Jacob and Israel what He has wrought to give us freedom in most lands, so that we will also be able to hold on to the land and vineyard in the Holy Land." (Klausner 1947, p. 45) He believed the Emancipation was a historic turning point because it allowed Jews to legally work for their own interests, on the one hand, while on the other hand it enabled individual Jews to rise in non-Jewish society both economically and politically, and to hold positions of influence that facilitated the implementation of national policies (Klausner 1947, p. 69). 
In the mid-1860s Kalischer contacted Adolphe Crémieux and succeeded in forging cooperation between the Kolonisations-Verein für Palästina, in which he was active, and the Alliance Israelite Universelle of which Crémieux was president. In a letter to his friend and colleague Elijah Guttmacher in 1866 he described the mutual effort as "a deed arranged by the Merciful One on High that Minister Crémieux will join with us." (Klausner 1947, p. 234) In October 1869 Kalischer traveled to Berlin on the occasion of a meeting of the Alliance. This was an opportunity for him to meet face-to-face with Crémieux in order to promote his ideas and plans for the settlement of Russian Jews in the Land of Israel (Klausner 1947, p. 320).

In 1836 Kalischer proposed to Rothschild that an altar be built on the Temple Mount and sacrifices be renewed, in order to hasten the Redemption. This is a clear expression of active theurgic-symbolic messianism, similar to the actions taken by HaGra's disciples:

When a larger number of the remnants of Israel gather in the Holy Land and Jerusalem, and they repair the destroyed altar and offer a sacrifice as a savory smell to God, then the Lord will be pleased to send the light of His countenance to descend upon His people (Translated in: Myers 2003, p. 62).

His operative plans in the 1860s for large-scale immigration of Jews to Eretz Israel from Russia, Romania, Serbia and Morocco, the purchase of land and the establishment of agricultural settlements and an agricultural school in Eretz Israel already expressed realistic active messianism. Starting from 1868 he suggested renewing those commandments that depended on the land to hasten the Redemption (Myers 2003, pp. 206-11), thus returning to a theurgic-symbolic active messianic conception alongside a realistic and active messianic conception.

The proposal of Kahana, who adhered to HaGra's halakhic and kabbalistic dictate to renew the observance of the commandments that depend on the land, including ceasing all agricultural work during shmitta for two consecutive years, even though "by nature [...] it will not succeed," points up the difference between theurgic-symbolic messianic activism per se and realistic messianic activism, which strives for practical success. Nevertheless, Kalischer believed it supported his position, since he did not feel that theurgic-symbolic activity contradicted realistic activity but rather complemented it, so long as it was not detrimental $^{14}$. Just as he initially believed that the idea of renewing the sacrifices completed the idea of settling Eretz Israel, so he finally believed in the idea of renewing the observance of commandments that depend on the land. In any event, when Kalischer presented Kahana's letter he omitted the proposal to observe shmitta for two consecutive years.

Along with the belief in theurgic-symbolic messianic activism and realistic messianic activism, Kalischer was open to accepting ideas that supported his teaching, even beyond the world of rabbinic tradition. After Moses Hess published his book Rome and Jerusalem (1862), in which he raised the idea of modern nationalism, calling on Jews to work towards the return to Eretz Israel, Kalischer adopted this modern concept ${ }^{15}$. In his articles on the German edition of Drishat Zion (1865) and its second edition in Hebrew (1866) he wrote explicitly about this nationalistic idea and made a requisite study of the national movements of the Italians, Hungarians and Poles ${ }^{16}$. In an article published in 1863 in the newspaper Der Israelit he wrote that in his opinion one of the goals of the Kolonisations-Verein für Palästina must be to "elevate the nationalism of Judaism." (Klausner 1947, p. 194) In his articles on the second edition of Drishat Zion (1866), Kalischer also wrote about love of the land, which must be learned from the national movements in Europe (Klausner 1947, p. 129). On the philosophical level, too, he preached of the national aspect, clarifying the place of the people in the overall fabric of Judaism. In his essay Shelom Yerushalayim (1868) he called the nation "the Israelite nation" in the triangle of Judaism: "God is one; in His Oneness He chose one Israelite nation..., one land as the heritage of the Israelite nation, and one Torah. These three are connected with a powerful bond, Israel, the Holy Land, and the Torah." (Klausner 1947, p. 132) This definition separates the national component from the other components of Judaism, giving it an independent aspect of respect, alongside religion but not part of it. 
Kalischer's most notable partner in his national ideals was Elijah Guttmacher (18741796). Guttmacher was born in Borek in the region of Posen. In his youth he studied at various yeshivas in Silesia. At the age of nineteen he joined the yeshiva of Akiva Eiger in Posen. In addition to studying Talmud and halakha, Guttmacher also studied kabbalah. In 1822 he was appointed rabbi of Pleschen. He established a large yeshiva attended by dozens of students. In 1839 he was appointed rabbi of Grätz near the Polish border. For a short time he was known throughout the area as a great tzaddik and many began flocking to him for advice, blessings and healing (Rafael 1983, pp. 448-49; Nissenbaum 1969, pp. 32-37).

Guttmacher enthusiastically welcomed Kalischer's book Drishat Zion. In 1862 he wrote: "... You have embarked on a great campaign to bring about the beginning of the redemption of Israel. Blessed is he who has merited such an opinion." (Klausner 1947, p. 100) He, too, was impressed by the equality of rights granted to Jews in Western European countries, and by the elevated positions achieved by individual Jews. He believed emancipation was a positive turning point in Jewish history which had not come about by chance. It was God's counsel that was allowing the Jews to return to their land. Like Kalischer, he too supported realistic messianic activism and believed that the redemption of Israel would not come about miraculously, but through nature, through the endeavors of Jews to settle the Land of Israel. He also supported active theurgic-symbolic messianism and the renewal of commandments that depended on the land (Hildesheimer 2015). In 1867 he wrote to the rabbi of Chikhanov:

Many mistakenly think that they can enjoy themselves with entertaining company as they do in their own homes, and suddenly the gates of mercy will open, and amazing deeds will be performed in heaven and earth and all the predictions of the prophets will be fulfilled and they will be summoned from their places of residence. Not so! [...] I say to you that we must settle the Holy Land and begin by taking the land out of its slumber at the hands of the Arabs, and observe all the commandments that are possible at this time, so that it will give fruit to the people of Israel. Even if only a few of Abraham's seed who come from Isaac and Jacob please the Lord in this, compassion and grace will come (Slutzky 1985, p. 41).

Like Kalischer, he too saw historical and technological changes as signs of divine providence on the one hand, and an opportunity to fulfill the vision of returning to Zion through nature on the other. He too supported the idea of the productivization of the Jewish community in the Land of Israel. He became Kalischer's main partner in his proto-national ideas and did whatever he could to advance his plans. Referring to their close cooperation, Kalischer wrote: "After all, we are almost the only ones who adhere together on this." (Klausner 1947, p. 310)

Guttmacher even put forward his own original idea, combining theurgic-symbolic messianic activism with realistic messianic activism. In 1874 he wrote to Rabbi Chaim Elazar Wax of Kalisz:

It is already clear to me that if 130 Jewish families are committed to working the Holy Land this will be the beginning of Redemption even if Israel does not deserve it [...] In Proverbs 102 there is a sign of compassion: The time will come when Your servants will desire its stones. [Rabbi Ovadia] Sforno says they were exiled because of the weariness of the earth. Through this correction Redemption will come (Slutzky 1985, p. 42).

Guttmacher referred to an agricultural settlement with a specific number of families-130, as a theurgic-symbolic correction, showing God the longing for the Land of Israel, which will hasten the coming of Redemption. This is no longer a religious act, where its connection with real success can not be seen, but a realistic act, a basic condition for true success, which in itself constitutes a kabbalistic correction.

In addition, Guttmacher believed that action should also be taken to strengthen Torah study in the Land of Israel. In 1860 he published a letter, Iggeret HaKodesh, which was also signed by Rabbi Yaakov Ettlinger of Altona, calling for Jews abroad to mobilize to increase 
Torah study in Eretz Israel by establishing batei midrash and maintaining scholars. The writers announced that their first act would be to adopt ten such scholars in Eretz Israel in the hope that others would follow in their footsteps. "Time will tell. Perhaps one day every father and mother who wishes to inspire their sons with Torah, the pure fear of God, and human wisdom - will send them to the Holy Land." (Rafael 1983, p. 451)

Judah Alkalay expressed a similar idea in the early years during which he held protoZionist ideas. In the 1840s he studied Midrash Aggadah in the Tractate Yevamot of the Babylonian Talmud, according to which "the Shechina does not descend on fewer than twenty two thousand of Israel." If twenty-two thousand Jews immigrate to Eretz Israel the Shechina will be restored to its place and Redemption will come. "In order to be redeemed we must restore twenty two thousand to the Land so that the Almighty God will bring down the Shechina upon them and then it will be seen as a good sign for us and for all Israel." (Raphael 1975, p. 237) The number of immigrants was not derived from any realistic analysis but from an authoritative religious source. Its practical impact was not explained rationally but through the concept of the Shechina, shrouded in secrecy. However, in his many subsequent works he focused mainly on realistic messianic activism, emphasizing the transformation of Eretz Israel into a settled land, the revival of the Hebrew language as uniting the Jewish people, and the convening of the Assembly of Elders to lead these enterprises.

\section{Gradual Transformation}

In contrast to the Zionist and counter-Zionist historiography of the descendants of HaGra's disciples, there was no steady aliyah to Eretz Israel throughout the century, but neither was there a revolution. Those who immigrated in the nineteenth century gradually moved away from the theurgic-symbolic messianic activism of Hagra's disciples towards integrated messianic activism: theurgic-symbolic and realistic in the style of Rabbis Kalischer and Guttmacher, who believed in a two-stage Redemption: natural and miraculous, and the continuation of realistic messianic activism embodied by Rabbi Alkalay, who himself immigrated to Eretz Israel, followed by Rabbi Moholiver, both of whom believed in a two-stage Redemption (Salmon 2014, p. 134), and culminating in realistic Zionist activism devoid of supernatural concepts, represented by Moses Hess, Pinsker, Lilienblum and their colleagues. The rabbis who were the proto-Zionists actually served as transformers from theurgic-symbolic messianic activism to realistic Zionist activism through their combined adoption of all these active approaches and the shift in emphasis from the symbolic to the realistic. Putting them all in the traditional messianic camp or the modern national camp distorts the picture. The great innovation of their doctrine was the transformation of the idea. The pioneers of the first Zionist aliyah and the intellectuals of Hibbat Zion claimed that their national pioneering resettlement motives were completely different from those of the religious settlers-who wanted to observe the commandments that depend on the land-or those of the Baalei halukah (the needy who depended on support) who founded Petah Tikva in 1878. But they did not insist that the redemptive activism of their motives was significant, nor did they emphasize their connection with the combined messianic activism of Rabbis Kalischer and Guttmacher. The founders of Petah Tikva rightly felt slighted by their attitude (Lilienblum 1899, p. 6; Salomon 1955).

Nevertheless, even in the 1880s-the period of the first Zionist aliyah, the echoes of theurgic-symbolic messianic activism still resonated among the immigrants to Eretz Israel. It is clearly reflected in the attitude of Rabbi Mordechai Gimpel Jaffe (1820-1891), who immigrated to Eretz Israel from Lithuania in 1888 and settled in Yehud, and in the shmitta controversy of $1888-1889^{17}$. The halakhic solution adopted by most of the new agricultural colonies was the heter mechirah (sale permit). The Ashkenazi rabbis of Jerusalem expressed their opposition to this permit.

Rabbi Mordechai Eliashberg (1817-1889) of Bauska published an open letter in HaMelitz against those who forbade work during shvi'it, claiming that some of them objected to the heter because they were opposed to the settlers in general and wanted to destroy the new 
settlements so that Baron Rothschild would withdraw his financial support. According to Eliashberg, their motive for opposing the settlements was the fear that the halukka would be withdrawn (Eliasberg 1888).

Jaffe published an open letter against Eliashberg's letter. He supported the Ashkenazi rabbis of Jerusalem and explained his position. He believed the Yishuv should not accept the heter, whether we believe that the sabbatical year, in our days, is ordained by the Torah or by Divrei Sofrim. He claimed that:

In any case, so far as this first sabbatical year is concerned, we should follow in the footsteps of our ancestors and masters who returned from exile, who took upon themselves the obligation of tithing even though they were exempt from it, and by solemn oath swore to uphold the tithes and observe the sabbatical years (Translated in: Luz 1988, p. 75).

In other words, upholding commandments that depend on the land is cardinal to observing religion in Eretz Israel, particularly in the present return to Zion. Observance of shemita is our declaration of intent that we have returned to Eretz Israel to renew our days as before, with all that it implies religiously. Just as those who returned to Zion in the time of Ezra and Nehemiah undertook to observe the commandments that depend on the land, even though they were halakhically exempt from them, so too must we conduct ourselves during the present return to Zion. For Jaffe, like Kahana, observing the shmitta properly was more important than the economic success of the agricultural settlement.

Despite the evolution of the ideology behind the motives for aliyah to Eretz Yisrael, throughout the 19th century, the original theurgic-symbolic version was still preserved among some disciples of the Vilna Gaon's students, illuminating the long ideological path that had been travelled during this period.

Funding: This research received no external funding.

Institutional Review Board Statement: Not applicable.

Informed Consent Statement: Not applicable.

Data Availability Statement: Not applicable.

Conflicts of Interest: The authors declare no conflict of interest.

\section{Notes}

At that time, a small group of Jews from Yemen also immigrated to Eretz Israel, inspired by messianic concepts.

For those terms, see: Bartal (1994), pp. 74-89.

For more about this letter, see: Yedidya (2018).

According to the Mishna, tractate Megilla 1,3, if there are fewer than 10 men it is defined as a village. On ten batlanim institution in Vilna (1864), see Shuchat (2008), p. 44.

On Torah study as a means of hastening the Redemption according to HaGra and his disciples, see also Shuchat (2003), pp. 163-66. For a similar, but not identical, idea, see: Kahana (1884), p. 103b.

This tradition also appears in Kahana (1884), p. 110a. It does not appear in the previous writings of Menachem Mendel of Shklov. On the practical adherence to the commandments in his writings, see: Baumgarten (2008), p. 302.

On Kabbalistic activities to hasten the Redemption in the early 20th century by seeking the Ten Lost Tribes, see: Meir (2016), pp. 96-134.

On Hibbat Zion, see: Vital (1975), pp. 65-134; Shimoni (1995), pp. 29-37; Goldstein (2016).

Michael Graetz related to them as a separate group he called the Nationalists, when he examined their enthusiastic attitude toward the establishment of the Alliance Israélite Universelle. Graetz (1996), pp. 249-55.

For more on Hess, see: Avineri (1985); Kohler (2017), pp. V-XXIII; Graetz (1980), pp. 133-53.

On Kalischer, see Myers (2003).

On the modernization of Kabbala see: Garb (2010).

Jacob Katz wrote that "The thought process of Rabbi Kalischer, composed wholly from time-hallowed traditions, did not absorb even an iota of an idea from the tenets of the modern nationalism". Katz (1958), pp. 224-5. It would appear that Katz was 
particularly impressed by the letter to Rothschild and Drishat Zion and paid no attention to the new ideas raised in the discussion that followed the publication of the book, including the central aspects of the modern national idea.

On the national movement in central and eastern Europe in the 19th century see: Berend (2003).

On this debate, see: Salmon (2019), pp. 255-72; Friedman (1974).

\section{References}

Avineri, Shlomo. 1985. Moses Hess: Prophet of Communism and Zionism. New York: New York University Press.

Barnai, Jacob. 1995. Historiography and Nationalism: Trends in the Research of Palestine and Its Jewish Yishuv 634-1881. Jerusalem: Magnes Press. (In Hebrew)

Baron, Salo. 1937. Aspects of the History of the Jewish Settlement in Jerusalem. In Sefer Klausner. Edited by Harry Torczyner, Aron Abraham Kabak and Baruch Shochetman. Tel Aviv: Va'ad Hayovel. (In Hebrew)

Bartal, Israel. 1994. Exile in the Homeland: Essays. Jerusalem: The Zionisnt Library. (In Hebrew)

Baumgarten, Eliezer. 2008. Tmunat Ha'otiot of R' Menachem Mendel of Shklov. Kabbala 18: 287-320.

Berend, Ivan T. 2003. History Derailed: Central and Eastern Europe in the Long Nineteenth Century. Berkeley: University of California Press. Dinur, Ben-Zion. 1955. At the Turning Point of Generations. Jerusalem: Bialik Institute. (In Hebrew)

Eliasberg, Mordechai. 1888. Michtav Galuy HaSheni. Ha-Melitz 28: 2835-38.

Etkes, Immanuel. 2019. The Messianic Zionism of the Vilna Gaon: An Invention of Tradition. Jerusalem: Carmel Press. (In Hebrew)

Ettinger, Shmuel. 1978. The Uniqueness of the Jewish National Movement. In Ideology and Zionist Policy. Edited by Ben-Zion Yehoshua and Aron Keidar. Jerusalem: Shazar Centre. (In Hebrew)

Friedman, Menachem. 1974. On the Social Significance of the Polemic on Shemita. Shalem: Studies in the History of the Jews in Eretz-Israel 1: 455-79.

Garb, Jonathan. 2010. The Modernization of Kabbalah: A Case Study. Modern Judaism 30: 1-22. [CrossRef]

Goldstein, Yossi. 2016. We Were First: A History of Hibat Zion, 1881-1918. Jerusalem: Bialik Institute. (In Hebrew)

Graetz, Michael. 1980. On the Return of Moses Hess to Judaism: The Background of 'Rome and Jerusalem'. Zion 45: $133-53$.

Graetz, Michael. 1996. The Jews in Nineteenth-Century France: From the French Revolution to the Alliance Israélite Universelle. Stanford: Stanford University Press.

Green, Abigail. 2010. Moses Montefiore: Jewish Liberator, Imperial Hero. London: Harvard University Press.

Hess, Moses. 1955. The Revival of Israel—Rome and Jerusalem: The Last Nationalist Question. Translated by Meyer Waxman. Lincoln and London: University of Nebraska Press.

Hildesheimer, Meir. 2015. The Settlement of Eretz-Israel in Rabbi Elijahu Guttmacher's Thought and Activity. In Time to ... Rabbi Zvi Hirsch Kalischer and the Awaking to Zion. Edited by Asaf Yedidya. Jerusalem: Yad Ben Zvi, pp. 103-29. (In Hebrew)

Idel, Moshe. 1998. Messianic Mystics. New Haven: Yale University Press.

Idel, Moshe. 2012. Messianic Scholars: On Early Israeli Scholarship, Politics and Messianism. Modern Judaism 32: 22-53. [CrossRef]

Kahana, Yitzhak. 1875. Sefer Yetsirah im Biur Hagra. Jerusalem: Defus Mikhel Hacohen.

Kahana, Yitzhak. 1884. Toledot Yitzhak. Jerusalem: Defus Shmuel Halevy Zukerman.

Katz, Jacob. 1958. Tzevi Hirsch Kalischer. In Guardians of our Heritage. Edited by Leo Jung. New York: Bloch.

Katz, Jacob. 1979. Jewish Nationalism. Jerusalem: The Zionist Library. (In Hebrew)

Klausner, Israel, ed. 1947. The Zionist Writings of Rabbi Zvi Kalischer. Jerusalem: Mossad Harav Kook. (In Hebrew)

Kohler, George Y. 2017. Renewed Messianic Thought in Nineteenth Century Germany: A Dispute Between Moses Hess and Leopold Loew. Daat 84: V-XXIII.

Laqueur, Walter. 2003. A History of Zionism: From the French Revolution to the Establishment of the State of Israel. New York: Schcken Books. Lilienblum, Moshe Leib. 1899. Derekh La'avor Golim. Warsaw: Achiassaf.

Lilienblum, Moshe Leib. 1953. Al Techiyat Israel al Admat Eretz Avoteiv. Jerusalem: The Zionist Organization.

Luz, Ehud. 1988. Parallels Meet: Religion and Nationalism in the Early Zionist Movement. Philadelphia: Jewish Publication Society.

Meir, Jonathan. 2016. Kabbalistic Circles in Jerusalem, 1896-1948. Leiden: Brill.

Morgenstern, Arie. 2006. Hastening Redemption: Messianism and the Resettlement of the Land of Israel. Oxford: Oxford University Press. Morgenstern, Arie. 2007. The Return to Jerusalem: The Jewish Resettlement of Israel 1800-1860. Jerusalem: Shalem Press. (In Hebrew)

Morgenstern, Arie. 2015. Striving for Zion: Messianism after the Sabbatean Crisis. Jerusalem: Maor. (In Hebrew)

Myers, Jody. E. 1991. The Messianic Idea and Zionist Ideologies. Studies in Contemporary Jewry 7: 3-13.

Myers, Jody E. 2003. Seeking Zion-Modernity and Messianic Activism in the Writings of Tsevi Hirsch Kalischer. Oxford: Littman Library. Nissenbaum, Yitzhak. 1969. Aley Cheldi. Jerusalem: Rubin Mass.

Pinsker, Leon. 1960. Herald of the National Rebirth: Auto-Emancipation and Its Critics: Open Letters, Speeches and Correspondence. Translated by Mordechai Yoeli. Tel Aviv: Messada. (In Hebrew)

Rafael, Yitzhak, ed. 1983. The Encyclopaedia of Religious Zionism. Jerusalem: Mossad Harav Kook, Vol. 1. (In Hebrew)

Raphael, Yitzhak, ed. 1975. Writings of Rabbi Yehuda Alkalai. Jerusalem: Mossad Harav Kook, Vol. 1. (In Hebrew)

Salmon, Yosef. 2014. Do Not Provoke Providence: Orthodoxy in the Grip of Nationalism. Boston: Academic Press.

Salmon, Yosef. 2019. Keeping Divine Law: Orthodoxy and Ultra-Orthodoxy. Jerusalem: Shazar Centre. (In Hebrew)

Salomon, Joel Moshe. 1955. Yehudah Vi-Yerushalayim. Edited by Getzel Kressel. Jerusalem: Mossad Harav Kook.

Shimoni, Gideon. 1995. The Zionist Ideology. Hanover: University Press of New England. 
Shuchat, Raphael. 2003. Messianic and Mystical Elements Associated with the Study of Torah According to the Gaon and his Disciples. In The Vilna Ga'on and His Disciples. Edited by Moshe Halamish, Tosef Rivlin and Raphael Shuchat. Ramat-Gan: Bar Ilan University Press, pp. 155-72. (In Hebrew)

Shuchat, Raphael. 2008. A World Hidden in the Dimensions of Time: The Theory of Redemption in the Writings of the Vilna Gaon Its Sources and Influence on Later Generations. Ramat-Gan: Bar Ilan University Press. (In Hebrew)

Shuchat, Raphael. 2015. The Principle and the Detail in the Thought of R. Isaac Kahana. Da'at 79-80: 119-35.

Slutzky, Avraham Ya'akov, ed. 1985. Shivat Zion. Jerusalem: Haor Sameach.

Vital, David. 1975. Origins of Zionism. Oxford: Oxford University Press.

Ya'ari, Eliezer. 1943. Iggrot Eretz Israel. Tel Aviv: Gazit.

Yedidya, Asaf. 2015. From Rothschild to Crémieux-The Israel's Notables in the Thought and Activity of Rabbi Zvi Hirsch Kalischer. Cathedra 155: 47-72.

Yedidya, Asaf. 2018. Between Internal Tikkun and External Tikkun and Between Symbolic-Theurgic Messianism and Realistic Messianism: The Vilna Gaon's Disciples and Rabbi Zvi Hirsch Kalischer. Cathedra 167: 27-58. 